\title{
PHYTOTOXICITY ANALYSIS OF VARIOUS PLANTS USING INDUSTRIAL SLUDGE
}

\author{
Deepankumar. $\mathbf{K}^{1}$, Narmadha. $\mathbf{N}^{2}$ \\ ${ }^{1} P G$ Scholar, Knowledge Institute of Technology, Salem, Tamilnadu, India \\ ${ }^{2}$ Assistant Professor, Department of Mechanical Engineering, Knowledge Institute of Technology, Salem, Tamilnadu, \\ India
}

\begin{abstract}
This paper deals with analysis of physical and chemical properties of sludge in dyeing industry.By seeding same kind of seeds in different materials such as red sand (A) and mixture of red sand \& sludge (B). By using this method to find out the phytotoxicity level of plant in PH,EC(ELECTRICAL CONDUCTIVITY),plant macro and micro nutrients level in both the materials, growth of stem\& root\& leaf in the material and the grown plants. With this we are concluding the toxicity level present in different material and the growth of plants.
\end{abstract}

Keywords: Industrial Sludge, Macro And Micro Nutrients, Agriculture, Organic Matter, Soil, Plant.

****

\section{INTRODUCTION}

Most of the research are based on sewage sludge used in agriculture purpose only. So its important to test the dyeing industrial sludge into the agriculture land. Mostly sewage sludge consist 65 to $75 \%$ of urines and laterins [6]. But in the dyeing industrial sludge consist of dyeing colours, cow duck, and some amount of different chemicals like lime, polyelectrolyte etc. Large part of sewage sludge are pollutes the environment depending on the chemicals used in the waste water treatment process [8].

In Nordic countries mostly $40 \%$ of sludge are used in agriculture purpose because of sewage sludge it contain high nutrients and organic matters. Micro and macro nutrients, manganese, copper, zinc are presented in sludge so it should be useable for plants [4].

In dyeing industry wastewater contain biological aspect of pathogens, including microbes, fungi, viruses, parasities and protozoa(biological properties). Some of the biological aspects are destroyed the growth of plants and thus causing contamination risk to animals, plants, peoples etc [7].

In waste water treatment cow duck also used for one part of water treatment. Cow duck contains some amount of nitrogen, phosphorus and potassium present. It should be helpful for growth of plants in agriculture. But most of the nutrients and nitrogens is lost immediately after some amount of chemicals used for the water treatment.

Interest in the agricultural usage of sludge obtained in water treatment plants is increasing due to the possibility of recycling valuable components ilke nitrogen, phrosphorus, organic matters and someother plant nutrients etc [2] . After either aerobic or anaerobic digestion process industrial sludge is the insoluble residue from wastewater treatment. Sludge comprises resistant compound $(60 \%$ of organic matter $),(6 \%$ nitrogen $),\left(4 \%\right.$ phosphorus $\left.\left(\mathrm{p}_{2} \mathrm{O}_{5}\right)\right)$, other macronutrients like $\mathrm{k}_{2} \mathrm{O}$ are $1.5 \%$.

The relationships of heavy metals have indirect effect of on soil, plant,and it affect its growth , nodulation in leguminous plant and other properties [3].

The experiment and the greenhouse conditions describe the effect of sewage sludge application to a desert soil on nodulation, nitrogen fixation and plant growth [5]. Due to toxicity effect of heavy metals plant analysis indicate that effect of sewage sludge in high rate rather than on host plants so the final result is sewage sludge at low usage rate may significantly increase legume growth in desert soil [1]. The Industrial sludge contain such as zinc, copper, Fe, Mn, $\mathrm{Cu}$ it may arise the problem when the industrial sludge is applied to an agricultural soil. The influence it heavy metal accumulation in the plants tissues and growth may be also occurred. For agriculture soil, sewage sludge studies are important due to economic and environmental implications.

\section{MATERIALS AND METHODS}

Take two part each filled with red soil one contain purely red soil (A) and another one contain mixture of red soil \& industrial sludge (B) contains soil density $\left(2 * 10^{6}\right) * 12$ tons/heter according to FCO(Fertilizer Control Order ). After that procedure sow different type of seeds in each part, in that measure the growth of plants in each 10 days $(10,20$, 30 days ones ). After the measurement we have to differentiate the growth of plants, root, stem, etc. The physical and chemical characteristics of material $\mathrm{A}$ and material B are shown in table (1).

Some of the physical and chemical characteristics and extractable $\mathrm{Fe}, \mathrm{Mn}, \mathrm{Zn}, \mathrm{Cu}$ amount of the soil and industrial sludge 
Table-1: Physical properties

\begin{tabular}{|l|l|l|}
\hline & LIME & Texture \\
\hline Material A & Normal & $82 \%(\mathrm{RS})$ \\
\hline Material B & Very high & $72 \%(\mathrm{RS} \& S)$ \\
\hline
\end{tabular}

Table-2: Chemical properties

\begin{tabular}{|l|l|l|l|l|l|l|l|}
\hline & $\mathrm{PH}$ & $\begin{array}{l}\mathrm{EC} \\
\mathrm{ds} / \mathrm{m}\end{array}$ & $\begin{array}{l}\mathrm{CaCo}_{3} \\
\%\end{array}$ & $\begin{array}{l}\mathrm{C} \\
\%\end{array}$ & $\begin{array}{l}\mathrm{N} \\
\%\end{array}$ & $\begin{array}{l}\mathrm{P} \\
\mathrm{Mg} / \mathrm{kg}\end{array}$ \\
\hline Material A & 8.1 & $\mathbf{1 . 1}$ & 2 & 0.2 & 0.64 & 16 & 140 \\
\hline Material B & 7.8 & $\mathbf{2 . 3}$ & 2.4 & 0.2 & 0.66 & 9 & 125 \\
\hline
\end{tabular}

Table-3: Extractable ions $\mathrm{mg} / \mathrm{kg}$

\begin{tabular}{|l|l|l|l|l|}
\hline & Fe & Mn & Zn & Cu \\
\hline Material A & 4.06 & 2.14 & 0.74 & 0.73 \\
\hline Material B & 4.00 & 2.12 & 0.90 & 0.70 \\
\hline
\end{tabular}

\subsection{Material (A)}

Material (A) contains full red soil (82\%) and $18 \%$ of some other mixture of soil and sands. In material(A) presented nutrients are $\mathrm{N}(0.61), \quad \mathrm{P}_{2} \mathrm{O}_{5}(0.257), \quad \mathrm{K}_{2} 0(1.1)$, $\mathrm{NH}_{2} \mathrm{CoNH}_{2}(1.325), \mathrm{H}_{2} \mathrm{PO}_{4}(1.605), \mathrm{FeSO}_{4}(65), \mathrm{MnSO}_{4}(50)$, $\mathrm{ZnSO}_{4}(300), \mathrm{CuSO}_{4}(60)$. these are the nutrients and organic matters are presented in normal red sand material (A).

\subsection{Material (B)}

Material (B) contain mixture of industrial sludge and red soil in the ratio of $10 \mathrm{~kg}$ red soil and 12.5 grms sludge and the presented nutrients are $\mathrm{N}(0.54), \mathrm{P}_{2} \mathrm{O}_{5}(0.245), \mathrm{K}_{2} 0(1.0)$, $\mathrm{NH}_{2} \mathrm{CoNH}_{2}(1.277), \mathrm{H}_{2} \mathrm{PO}_{4}(1.654), \mathrm{FeSO}_{4}(63), \mathrm{MnSO}_{4}(52)$, $\mathrm{ZnSO}_{4}(334), \mathrm{CuSO}_{4}(66)$.

\section{RESULT AND DISCUSSION}

Due to high dose of EC(electrical conductivity) and lime presented in material (B). The growth of the plant will be totally reduced when compare to material (A).

$\mathrm{EC}_{1: 1}$ If Readings less than $1 \mathrm{dS} / \mathrm{m}$, then the soil are considered as non-saline and do not impact most crops and soil microbial processes. $\mathrm{EC}_{1: 1}$ If Readings greater than 1 $\mathrm{dS} / \mathrm{m}$, then the soil are considered as saline and impact important microbial processes, such as nitrogen cycling, production of nitrous and other $\mathrm{N}$ oxide gases, respiration, and decomposition; population of plant-parasitic nematodes can increase; and increased nitrogen losses [9].

The lime will reduce the plant growth by inhibiting the intake of major plant nutrients (nitrogen, phosphorus and potassium). In water treatment process, lime is used for purifying the waste water so the lime presented in the material (B) is very high and the EC(electrical conductivity) is 2.3 .

In growth of the plant 1).LablabPurpurreus 2).Abelmoschus Esculentus in material (A) \& material (B),chemical properties, Extractable ions $\mathrm{mg} / \mathrm{kg}$ are shown in chat and fig.

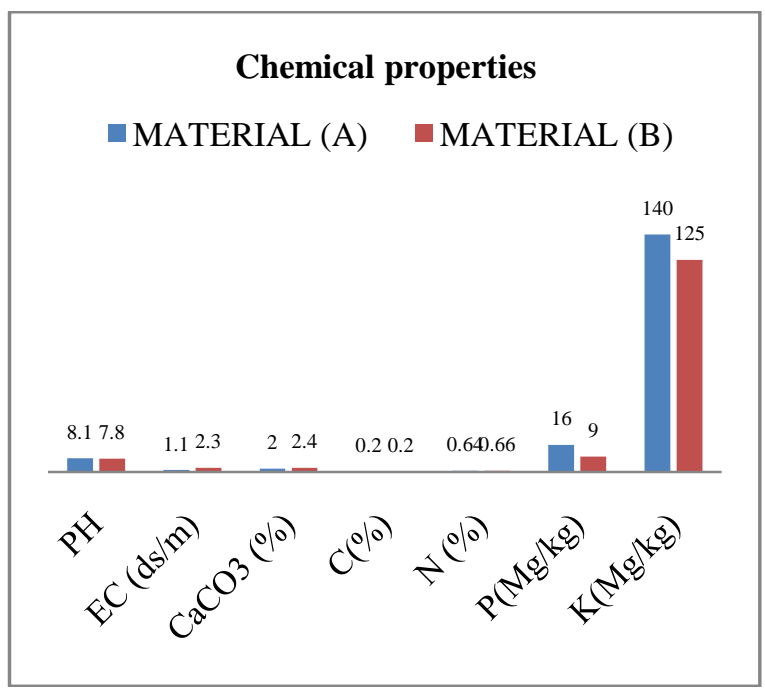

(A) 


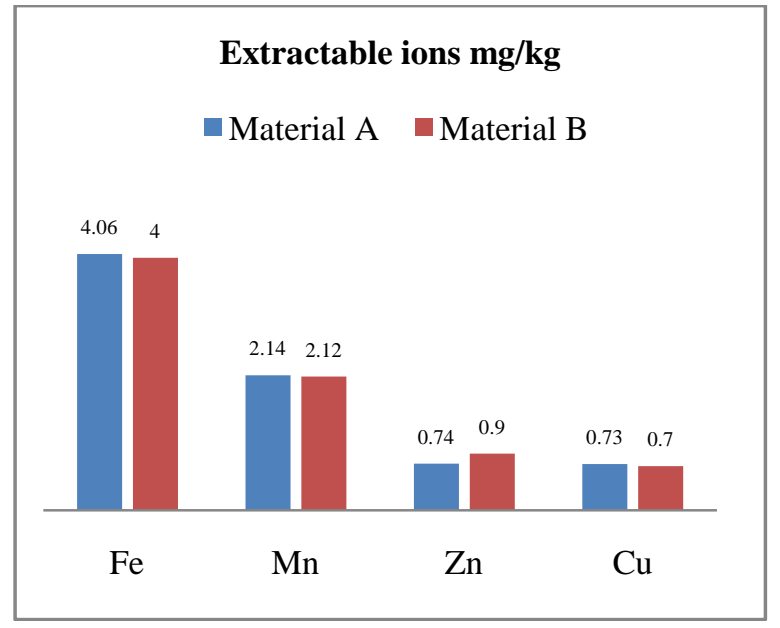

(B)

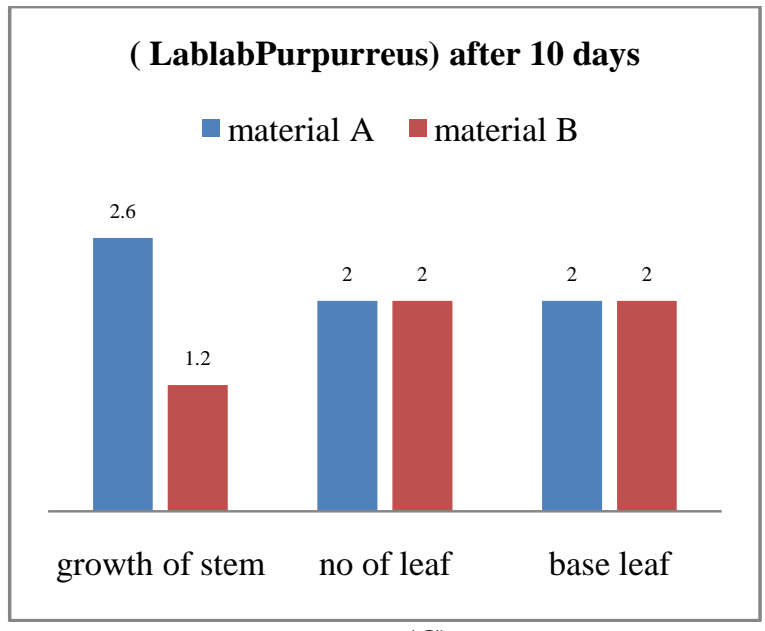

(C)

\section{DAY-1}

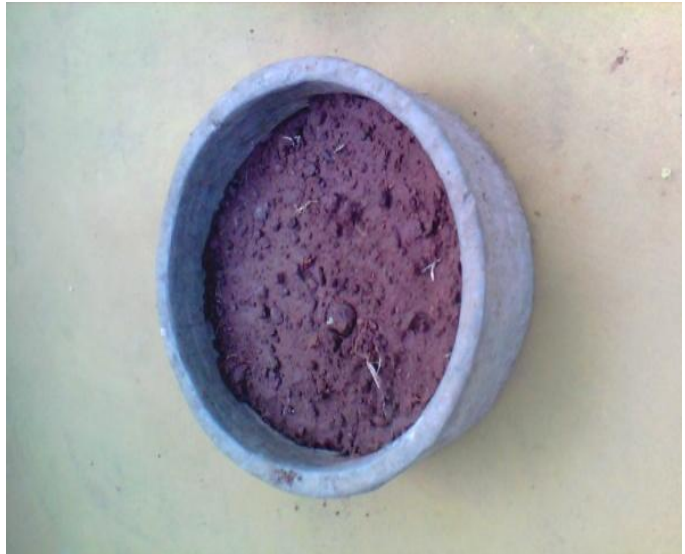

Fig -1: MATERIAL (A) DAY-1

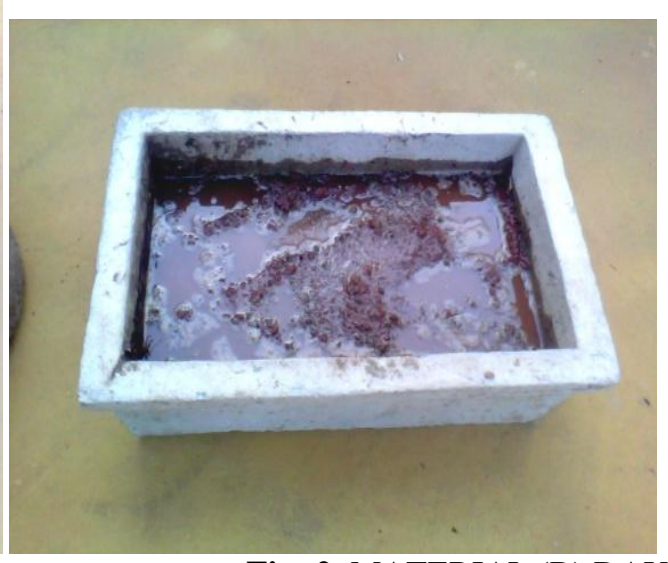

Fig -2: MATERIAL (B) DAY-1

Both the materials seeded with two types of plants they are 1).LablabPurpurreus 2).Abelmoschus Esculentus

\section{AFTER $10^{\text {th }}$ DAYS}

Fig -3: MATERIAL (A) after $10^{\text {th }}$ day

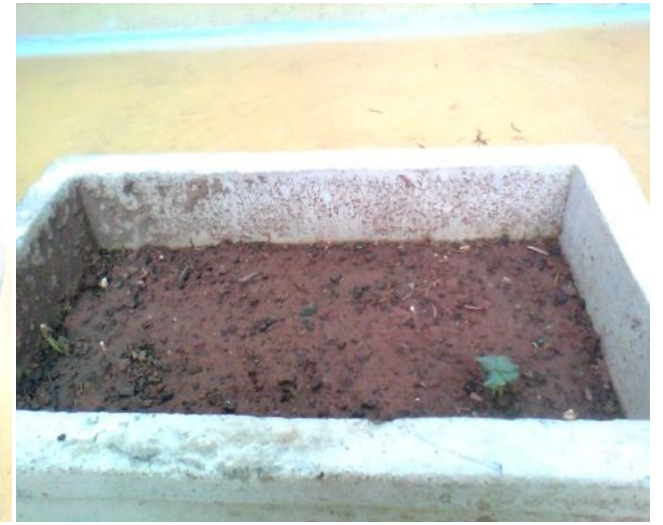

Fig -4: MATERIAL (B) after 10th day

Material (A)( LablabPurpurreus)

The Growth of stem- $2.6 \mathrm{~cm}$, number of leaf-2,base leaf-2

Material (B)

The Growth of stem-1.2cm, number of leaf-2,base leaf-2 


\section{AFTER 20 ${ }^{\text {TH }}$ DAYS}

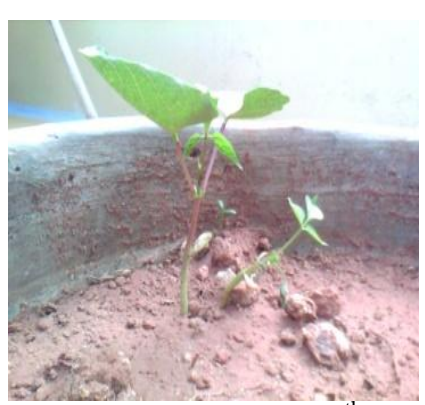

Fig -5: MATERIAL (A) after $20^{\text {th }}$ day
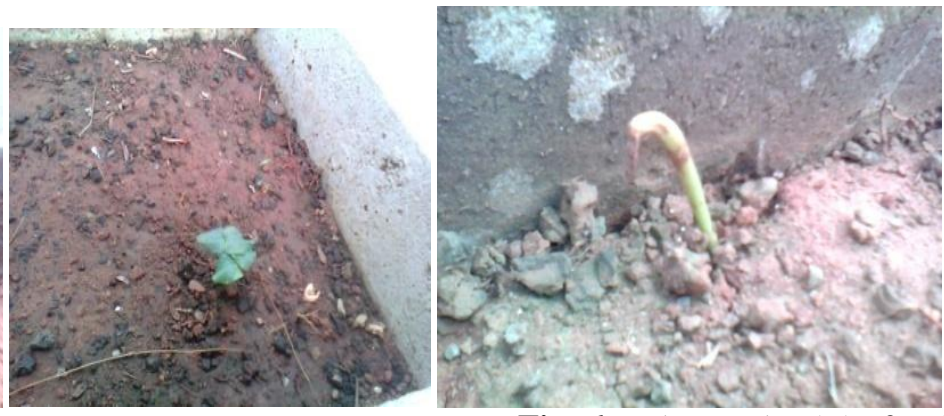

Fig -6: MATERIAL (B) after 20th day

Material (A) ( LablabPurpurreus)

The Growth of stem- $4.7 \mathrm{~cm}$, number of leaf-4,base leaf-2

Abelmoschus Esculentus

The Growth of stem- $1.7 \mathrm{~cm}$, number of leaf-2,base leaf- 0

Material (B) ( LablabPurpurreus)

The Growth of stem-2.0cm, number of leaf-0,base leaf-0

\section{AFTER 30 ${ }^{\text {th }}$ DAYS}

Fig -7: MATERIAL (A) after $30^{\text {th }}$ day

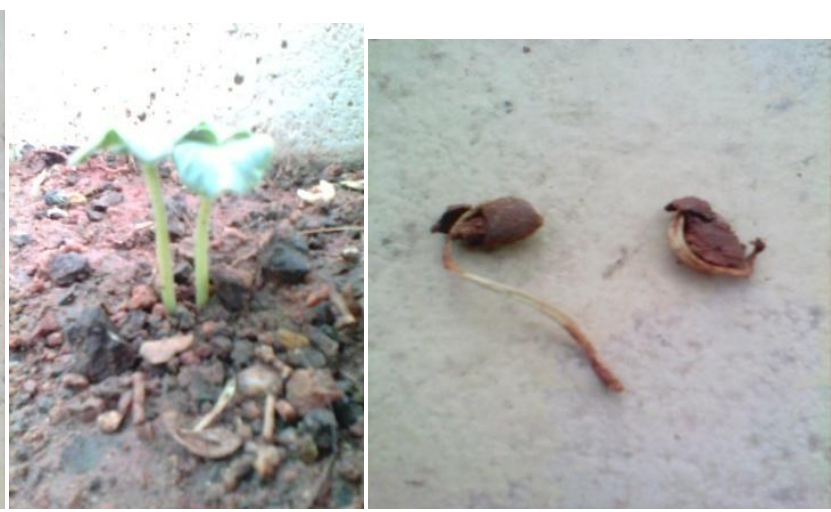

Fig -8: MATERIAL (B) after 30th day

Material (A) ( LablabPurpurreus)

The Growth of stem-7.2cm, number of leaf-5,base leaf- 2

Abelmoschus Esculentus

The Growth of stem-2.8cm, number of leaf-2,base leaf- 0

Material (B) ( Lablab Purpurreus)

The Growth of stem-2.0cm,number of leaf-0,base leaf-0

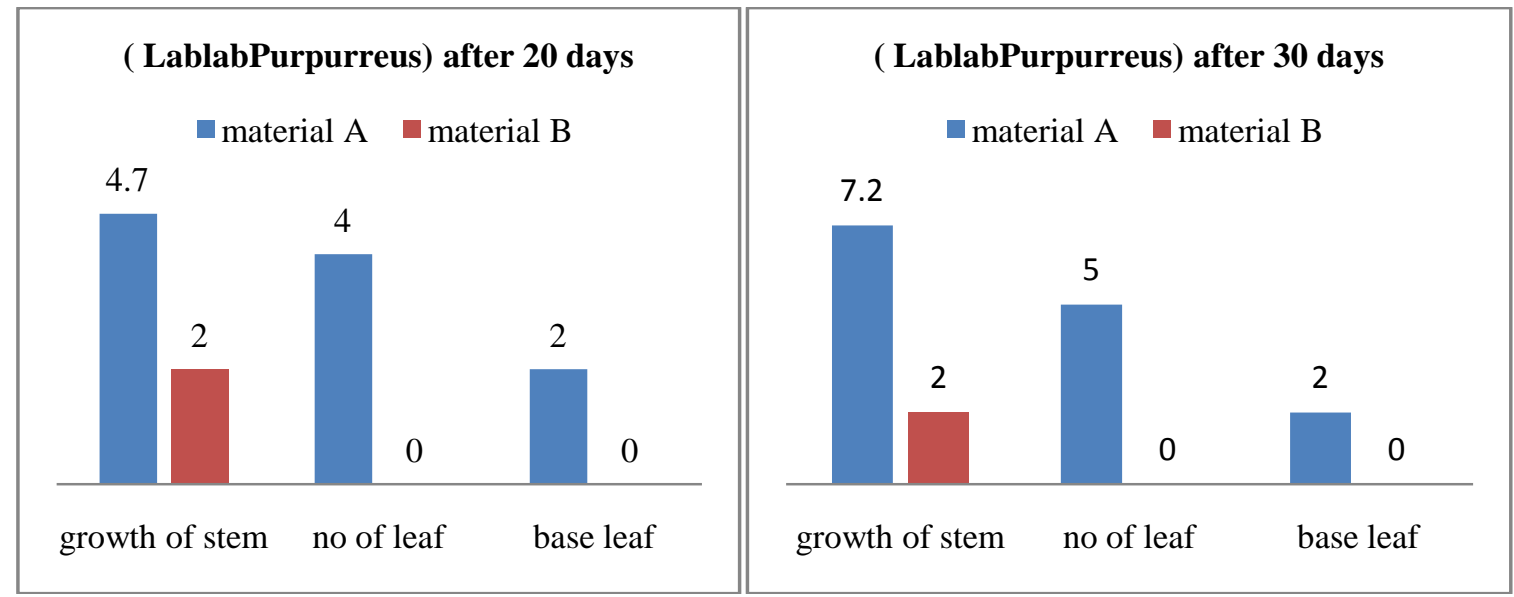

(D)

(E) 
In conclusion, the usage of industrial sludge in the agriculture purpose is highly toxicity, due to the presence of high lime and electrical conductivity. Therefore the industrial sludge reduces the growth of plants. In future the neutralization of toxicity level in sludge should be used for agriculture purpose.

\section{REFERENCES}

[1]. Abd - Alla, M.H ;Yan - Feng ; S.Schubert (1999) : Effect of sewage sludge application on Nodulation, nitrogen fixation, and plant growth of Faba bean, Soybean and lupin. Angewandte- Botanik, Germany.73(3/4):69-75

[2]. Chaussod, R;J.C. Germon; G.Catroux (1978): Determination de la fertilisante des boues residuaires.Aptutude A liberer la' zote.Ministe re de l'environement et du cadre de vie .Convention de tude n.74050(in French).

[3]. Heckman,J.R;J.S.Angle;R.L.Chaney(1986):Soybean nodulation and nitrogen fixation on soil previously amended with sewage sludge. Bio.fertil.soils, 2:181- 185.

[4]. Heinonen-Tanski, H. \& Jantunen, P. 1997. Ymparivuotisten Makela-Kurtto, R. 1994. Jatevesilietteen kasittely ja sijoitus: ympariston tukimuspaivat 11. 12.10.1993, Kuopio. Vesi-ja ymparistohallituksen monistesarja nro 550 .

[5]. Hussein kh. Ahmed, Hassan a. Fawy \& e.s.abdelhady(2010): study of sewage sludge use in agriculture and its effect on plant and soil.Agric. Biol. J. N. Am., 2010, 1(5): 1044-1049

[6]. Jonsson, H. 1995. Assesment of sanitation systems and reuse of urine. Ecological alternatives in sanitation. Proceedings from Sida Sanitation Workshop. Balingsholm, Sweden 6-9 August 1997. Publications on Water Resources nro 9. P. 11-22.

[7]. Lehmann, D.L. \& Wallis, P.M. 1983. Literature review - Occurence and survival of pathogenic bacteria in sludge and on soil. In book: Biological health risks of sludge disposal to land in cold climates. Eds. Wallis, P. M. Ja Lehmann, D.L. University of Calgary Press. 388 p.

[8]. Steineck, S., Stintzing, R., Rodhe, L., Elmquist, H. \& Jakobsson, C. 1999. Plant nutrients in human urine and food refuse. Use of municipal organic waste. Proceedings of NJF seminar no. 292, November 23-25, 1998 Agricultural Research Centre, kioinen, Finland. DIAS report Plant Production no. 13, June 1999. 2nd volume, p. 125-130.

[9]. USDA-NRCS: Soil Electrical Conductivity - Soil Quality Kit(Guides for Educators) 